\title{
Clearing the Way for Civil Society in South-eastern Anatolia: The Importance of Trust and Discourse
}

\author{
Hakan Samur
}

\begin{abstract}
This article discusses one of the problems that must be resolved urgently in order to enable the development of civil society in the South-eastern Anatolian Region. This is a region that will likely become the future eastern border area of the European Union (EU) and is currently Turkey's most troubled region due to its political, economic and social conditions. Despite the fact that a suitable legal-institutional environment was established during the EU membership process especially after 2001 , one of the most significant obstacles that prevents civil society in the Region from showing the effort to benefit from this environment is the fact that due to from long-standing conflicts and oppressive policies, it has not been possible to establish an environment of trust between the state and civil society. First and foremost among the most crucial tools that must be reviewed and considered to establish such an environment of trust is the discourse employed by the politicobureaucratic elite.
\end{abstract}

IN THIS STUDY, THE CIVIL SOCIETY PHENOMENON WILL BE ANALYSED IN A SMALL geographic area, Turkey's South-eastern Anatolian Region. In this introductory section the characteristics and increasing regional, continental and global importance of civil society as well as the specific perspective of the study will be explicated.

Although civil society is generally defined as collective associations, movements or networks distinct from the state, markets or the private arena (family), in which people participate on a volunteer basis and enjoy great autonomy, it is not entirely clear what these specific structures actually entail (Newton 1999: 10; Wagner 2006). While there is consensus regarding the fact that the market (organisations of production and distribution) and family are not within the realm of civil society, different approaches exist in relation to the status of, for instance, political parties. Some (Deth 1997: 1; Newton 1999: 10) include political parties within the circle of civil society, whereas Cohen and Arato (1997) argue that since political parties aim to gain control of and manage state power directly, they must be considered as part of political society. However, Cohen and Arato (1997) also state that civil society is the most significant source that nourishes political society, that the mobility of civil society plays a complementary role to party systems (within the context of rights and freedoms, and democratization), and that the political role of civil society should not be to directly control the administration in power but to the generation of influence. Thus, even if political parties are considered to be a part of civil society or political society in general, it would not be erroneous to say that in such cases, they execute the functions of civil

I would like to thank the Scientific and Technological Research Council of Turkey for supporting the research study I conducted at the University of Manchester, which also provided the groundwork for this paper. I also would like to thank the Jean Monnet Centre of Excellence in Manchester and Professor Stefan Berger for providing me the opportunity of working at the University of Manchester. Finally, I would like to thank two anonymous reviewers for their useful comments and Eamonn Butler for his assistance. Vol. 4, No. 3, pp. 224-239. Available: http://www.jcer.net/ojs.index.php/jcer/article/view/101/107 
society. As will be explained below, when the conditions of the target region of the present study are taken into consideration, it becomes necessary to judge especially electoral participation as being in line with the functions of civil society.

Civil society may take on organisational and non-organisational forms. Structures founded based on principles of volunteerism or non-profit, and also called volunteer organisations or non-governmental organisations, constitute the organisational form of civil society. Various activities (demonstrations, campaigns, boycotts, mass meetings) that overlap with the functions that will be delineated below and realized mostly under the leadership of one of these organised structures constitute its non-organisational form. The functions (roles) of civil society may be classified as below:

Distributive Function (Economic and Social Roles): Especially in cases where the state is inadequate, civil society organisations perform economic and social functions in line with their founding aims by providing either healthcare, food and welfare services, as well as educational and cultural services to its members, the society at large (or even internationally) (Edwards 2004).

Representative Function: Civil society organisations are assumed to be the representative as well as the articulated forms of interests and orientations in society. In other words, they reflect the interests and demands of society in general (Deth 1997: 2).

Mediating Function: In reflecting these interests and demands, they undertake numerous activities so as to influence governmental organisations, and enable communication between these organisations and social interests (Deth 1997: 2; Newton: 1999).

Political Function: This is one of its most crucial functions. While civil society acts as a societal control mechanism to prevent the misuse of power by the state and political organisations, and ensure transparency, it also generates alternative projects and recommendations for these organisations as well (Hall 1995; Moyser and Parry 1997: 25; Edwards 2004). This function is not necessarily against government and state; it can also be open to collaborative efforts (Norton 1995).

Civil society is widely considered to be one of the most important factors in the basis of the development of Western European societies in the existing literature. In this respect, there are many who credit civil society for the developmental path that has led the Western part of the continent to a different and ultimately more desirable economic and political structure compared to its Eastern part (Chirot 1989; Hall 1995: 4; Bideleux and Jeffries 1998). Paradoxically, the pioneering impact of civil society organisations on regime changes in Eastern European nations has played a large role in the revival of the civil society concept from the 1990s onwards (Agh 1998; Cohen and Arato 1997; Edwards 2004). In these nations, civil society is deemed significant not only because of its role in the regime change, but also of its role during the extensive economic and political transformation processes these nations underwent in the post-Communist era. This is rooted in the fact that civil society has enjoyed a critical role in terms of input and output during these transformation processes. In other words, while the existing civil society of the time played a role in the success and content of the transformation process in the new environment formed by democratization and the introduction of the market economy, civil society acquired new status and quality. The roles attributed to civil society have been more visible in some nations, and vaguer in others.

The European Union (EU) has also had an effect on the rising role of civil society. In parallel with increasing deepening efforts and an "ever closer Union" attitude since the mid-1980s, increased dialogue between EU citizens and civil society groups in the Union has over time become more and more important. As a result of the changes that emerged in Central and Eastern Europe and the membership applications by these 
countries to join the EU, the importance and role of civil society had been voiced with increasing frequency, particularly since the late 1990s when programs geared toward civil society have become a main focal point (COM 2001; Smismans 2005). Ultimately, the trend of civil society organisations expanding beyond national borders has not been specific only to the EU; it can be observed at a global level. While there were only 176 NGOs with international characteristics in 1909, this figure reached 28,900 by 1993 (Hulme and Edwards 1997: 4).

In this study, the situation of civil society in the South-eastern Anatolian Region will be discussed on the basis of a matter that must be given due importance to enable civil society to develop and ensure that benefits expected from the crucial democratic-legal reforms enacted within the context EU harmonisation are realized; namely, trust. It is argued that for the political environment in the Region to normalize, for dialogue and democratic channels to function, and for civil society to flourish within the context of its fundamental principles, first, an environment of trust needs to be established between the state and society. Primary among the methods to achieve this end is to determine the content of the discourse between policy makers/implementers and the public. In the first section below, a summary of information will be provided on the overall characteristics and socio-economic and political profile of the Region. It will also provide an overview of the current status of civil society. Later, the issue of trust and the impact of discourse on trust will be elaborated in the following two sections.

The fact that a specific geographic area has been examined should not be perceived as though the subject matter and subsequent analyses will hold meaning only for this region. The necessity but scarcity of studies on societal structures and processes (Delanty and Rumford 2005: 1), or the importance of conducting studies on a "microsociological level" in relation to the status of societal actors, such as civil society organisations, in the context of the Europeanisation process (Bulmer and Lequesne 2002: 29) is apparent. The concept of Europeanisation can be used to refer to different things in the existing literature; in this study, it is used to express the process of change in the domestic structures of member or candidate states within the context of EU norms and practices. The aforementioned change is a phenomenon that comprises not only legal-procedural aspects, but also normative ones (informal rules, styles, "ways of doing things", shared beliefs, etc) (Radaelli 2003: 30).

Since a systemic transformation within the context of a new political and economic approach is not the case here, it would be wrong to consider the process of change in South-eastern Anatolia in the same category as that evidenced in Central and Eastern Europe. However, it should be noted that if the economic and especially the political conditions in our focal region, South-eastern Anatolia, are to change during the Europeanisation process, and considering the output level hoped to be achieved, it would not be wrong to call this process an instance of "semi-transformation". In addition, due to the political and economic conditions, the South-eastern Anatolian Region has become Turkey's 'weakest link' and thus, in terms of civil society, is both an interesting and critical case for Turkey and for the EU, of which Turkey is a candidate country.

\section{The South-eastern Anatolian Region and the current status of civil society in the Region}

The socio-economic and political environment of the Region

Known as 'South-Eastern Anatolia' in Turkey's geographical zoning system, the region in question covers the Euphrates and Tigris Basins and the surrounding area and stretches over nine provinces. The Region also covers three Eurostat regions as set out 
by Eurostat's zoning system, NUTS (Nomenclature of Territorial Units for Statistics): ${ }^{1}$ These regions are TRC1 (provinces of Gaziantep, Adıyaman, and Kilis), TRC2 (provinces of Şanlıurfa and Diyarbakır) and TRC3 (provinces of Mardin, Batman, Şırnak and Siirt). The total population of the region by the end of 2007 was 2,336,657 and it covered a land area of $76,506 \mathrm{~km}^{2}$.

The World Alliance for Citizen Participation (CIVICUS) determined eight conditions that could affect the activities of civil society (TUSEV and CIVICUS 2006: 68): widespread poverty; armed conflict; ethnic and/or religious tension; a large economic crisis; the proportion of the population impacted by natural disasters; disparate socio-economic conditions; widespread adult illiteracy; and inadequate infrastructure for information technology. It is not within the scope of this study to examine the South-eastern Anatolian region in detail in terms of each of these conditions, however, the general information provided below on the socio-economic and political conditions of the region will clearly show that perhaps with the exception of natural disasters, civil society is striving to find a developmental path in a rather unfavourable environment in terms of all the other conditions.

Regarding socio-economic development, it is observed that the provinces in the region are not at an inspiring level, and with the exception of Gaziantep, situated in the western part of the Anatolian region, all other provinces have a negative development index and are very much behind the 81 provinces in Turkey (see Table 1). While Turkey's GDP per capita was $€ 5,300$ in 2001 and already much lower than the over $€ 20,000$ average of the EU-25 (Eurostat 2007), according to the Turkish Board of Statistics which provided data for that same year (TUIK 2001), the per capita income for the region in 2001 was only $\$ 3,389(€ 2,800)$. Although more current and precise data for the Anatolian region does not exist, considering that the Eurostat data for the EU-25 was $€ 23,400$ and $€ 7,200$ for Turkey in 2005, a significant change in the Region would seem highly unlikely.

Table 1: Provinces in the Region by socio-economic development

\begin{tabular}{|l|l|l|}
\hline Province & $\begin{array}{l}\text { Socio-economic } \\
\text { development index* }\end{array}$ & $\begin{array}{l}\text { Socio-economic } \\
\text { development ranking } \\
\text { (among 81 provinces) }\end{array}$ \\
\hline Adıyaman & -0.77647 & 65 \\
\hline Batman & -0.90456 & 70 \\
\hline Diyarbakır & -0.66993 & 63 \\
\hline Gaziantep & 0.46175 & 20 \\
\hline Kilis & -0.41175 & 54 \\
\hline Mardin & -0.98944 & 72 \\
\hline Siirt & -1.00644 & 73 \\
\hline Şanlıurfa & -0.83158 & 68 \\
\hline Şırnak & -1.13979 & 78 \\
\hline
\end{tabular}

* This index was calculated based on 58 different indicators, including demographics, employment, education, health, industry, agriculture, construction, finance, infrastructure, etc.

Source: Dincer, B. et al. (2003). illerin ve Bölgelerin Sosyo-Ekonomik Gelişmişlik Sıralaması Araştırması2003. [Study on the Socio-economic Development Ranking of Provinces and Regions-2003] Ankara: State Planning Organisation (Pub No: 2671), p. 55.

A study conducted by the Turkish Board of Statistics based on Eurostat criteria showed that while the poverty line rate was 23.8 for Turkey in 2003, this rate was 35.09 per cent in TRC1 (Gaziantep, Adıyaman, and Kilis), 64.33 per cent in TRC2 (Şanlıurfa and Diyarbakır), and 82.37 per cent in TRC3 (Mardin, Batman, Şırnak, and Siirt) (Dansuk et al.

\footnotetext{
${ }^{1}$ See: http://ec.europa.eu/eurostat/ramon/nuts/codelist en.cfm?list=cec, last accessed 5 March 2008.
} 
2006). One out of every four inhabitants in the region is illiterate (26.8 per cent), and this rate reaches as high as 40 per cent among women (TUSIAD 2006: 75).

Regarding the political environment, starting from the establishment of Turkish Republic, the state tended to ignore the existence of Kurdish ethnicity until very recently and pursued an assimilation policy. This approach created continuous tension within the region. This was particularly so, when during the first period of Martial Law and then during the Declaration of a State of Emergency in the region from 1980 to 2002, oppressive policies of the state that ignored problems or legitimate demands within the context of human rights not only resulted in no favourable outcomes, but also brought to the fore divisive groups that approved of terrorist acts. This situation greatly intensified in the 1990s, especially after radical Kurdish groups carried out terrorist acts under the umbrella of the Kurdistan Workers' Party (PKK - Partiya Karkerên Kurdistan) from the mid-1980s onwards, and the state responded by using almost only military methods as a means to resolve the issue. The armed conflict has to date claimed at least 35,000 lives (Freedom House 2007: 12), and hundreds of thousands of people, including religious-cultural minorities, have been either forcibly displaced or had to relocate by choice due to the events that transpired. Thus, a large proportion of the public was treated as potential criminals as a result of the situation in the Anatolian region, which was also described by top-level military officials of the time as a "low intensity war".

It must be noted here that since 2001, Turkey has embarked on a series of crucial reforms designed to aid its EU accession process. In the space of a few years, Turkey has ratified legal regulations that have enabled important harmonisation changes; something which had always been postponed previously. In this new period, the law and human rights have a much higher profile and a number of social and cultural rights, that had been denied in the 1990s, now took on greater significance within people's everyday life; for example, broadcasts in a mother tongue and the freedom to learn this language, improved regulations made in the area of freedom of thought, and changes made to the Anti-Terror Law, etc. Called the most important reforms of the history of the Turkish Republic (Aktar 2003; UPSAM 2006; ESI 2007), and earning favourable reviews not only in the region or nationally but also among EU circles, these reforms brought noteworthy and positive changes in terms of the advancement of civil society. For NGOs, which until recently (1) were strictly monitored and under observation by both the police and other state authorities, (2) functioned despite excessive bureaucratic difficulties and (3) had to obtain special permission in order to establish international contacts and run international projects, these reforms not only lifted restrictions in relation to organisational freedoms and civil rights to a large extent, but also brought new approaches to human rights and social policies, helping the establishment of an environment conducive to dialogue for the resolution of problems (TUSEV-CIVICUS 2006).

Another development that has gained pace from 2001 onwards is EU's support of civil society in Turkey. In addition to an extensive Civil Society Development Programme, the civil society organisations in the Anatolian region have been benefiting from various programmes geared toward the country at large, including the European Initiative for Democracy and Human Rights, and Education and Youth Programmes. In addition, programmes geared specifically toward the region and aiming mainly to benefit civil society organisations such as the Cultural Heritage Development Programme of the GAP, Development Programme of the GAP Region and GAP Entrepreneur Support Centre, were all initiated after 2001.

\section{Current size of civil society and the legal environment}

As can be expected, in the shadow of the negative socio-economic and political indicators, civil society was also rather restricted especially until 2001. Figures for non- 
profit and volunteer associations are presented in Table 2 . Although the population in the Anatolian region is over 2,300,000, there are only 2,792 volunteer organisations overall and total membership amounts to 149,174 . These figures, however, do not reflect the real situation because, according to the Law of Associations, a volunteer association can be founded by a gathering of at least seven people. Therefore, a lot of associations are founded through nominal membership of close friends and relatives. Also it should be noted that most of the associations have been launched after 2001 demonstrating the impact of Europeanisation process. For example, in Diyarbakır, the foundation date of 67 per cent of those 512 associations has been after $2001 .^{2}$

Table 2: The number of and membership to volunteer organisations in the South-East Anatolia

\begin{tabular}{|l|l|l|l|}
\hline Province & \multicolumn{1}{|c|}{$\begin{array}{c}\text { Number of Active } \\
\text { Associations }\end{array}$} & $\begin{array}{c}\text { Within-Country } \\
\text { Percentage }\end{array}$ & \multicolumn{1}{|c|}{$\begin{array}{c}\text { Number of } \\
\text { Members* }\end{array}$} \\
\hline Adıyaman & 349 & $0.44 \%$ & 14.269 \\
\hline Batman & 150 & $0.19 \%$ & 8.365 \\
\hline Diyarbakır & 512 & $0.65 \%$ & 23.276 \\
\hline Gaziantep & 774 & $0.99 \%$ & 61.028 \\
\hline Kilis & 88 & $0.11 \%$ & 3.120 \\
\hline Mardin & 184 & $0.23 \%$ & 7.661 \\
\hline Siirt & 162 & $0.20 \%$ & 4.819 \\
\hline Şanlıurfa & 505 & $0.64 \%$ & 24.219 \\
\hline Şırnak & 68 & $0.08 \%$ & 2.417 \\
\hline TOTAL & 2792 & $0.35 \%$ & 149.174 \\
\hline
\end{tabular}

*Data gathered through electronic correspondence with the Ministry of Home Affairs.

Source: http://dernekler.icisleri.gov.tr/Dernekler/Kurum/lllereGoreDernekSayisi.aspx, last accessed 13 March 2008.

Civil society has problems not only in terms of quantity, but as can be expected, of quality as well. The results of an extensive study conducted with NGOs in the region (içcluygu and Dane: 2005) revealed that NGOs were financially weak, inadequate in respect of expertise and organisation, somewhat partisan in character, some groups were alienated from society and had no structure to represent them (for instance, homosexuals). All NGOs also experienced mistrust in their relations with the state, were ineffective in terms of influencing policies (political function) and much less effective in rural areas. Furthermore, the levels of participation by women were low.

At this point, we might also briefly look at electoral participation, which functions as civil society in terms of revealing public reaction and the public's desire to influence political processes. An assessment that also included Southern Italy and some Central and Eastern European regions found that the South-eastern Anatolian region was among those that had the lowest electoral participation in the EU (OECD 2007: 130). Even at the most recent general elections that took place on 22 July 2007, at a time when political tensions in the country were high and voter turnout reached the second highest level ever (84.6 per cent), electoral participation remained five to fifteen points below this figure in the various provinces across the Anatolian region. Electoral participation was at a much lower level in previous elections. ${ }^{3}$ Considering the political and economic problems in the region, one would expect much higher voter turnout as

\footnotetext{
${ }^{2}$ Data collected from Diyarbakır Governorship, Directorate of Associations.

${ }^{3}$ Results obtained from the web site of the Supreme Electoral Board. http://ysk.gov.tr/ysk/index.html (last accessed 10.03. 2008).
} 
a means to indicate their reactions to offered solutions. On the contrary, however, boycotting the election due to anger toward the state and the belief that 'nothing will change' is also a possibility. Still, it must be said that a weak civil society and civic passivity are also important factors that lie at the basis of low levels of electoral participation.

As a result of the inadequacy of civil society and an oppressive legal-political environment, acts of terrorism and violence have dominated the region, as the previously mentioned figures show. Consequently, even non-organisational forms of civil society activities (public protests and demonstrations) have not fully been utilized. The legal changes, and the specific support provided to the region by the EU have in recent years opened the way to improvements in the societal structure of and civil society in the Anatolian region. However, these improvements took root after 2001, in the optimistic environment generated by EU harmonisation reforms and expectations that the reforms would be ongoing. In addition, as of the present, these improvements have unfortunately not been comparable to the astounding speed of the changes experienced in the legal context that is recognized even by NGOs themselves, and not transformed to regional peace and complete renewal of state-civil society relations. The fact that suspicions remain concerning the development of civil society in the region despite the strengthening of the legal-democratic environment, means the root of the problem lies elsewhere. Therefore, it is possible to suggest that trust, the sense of feeling safe in relation to others, is the key concept in terms of the source and resolution of the problem.

\section{Developing an Environment of Trust}

Whiteley and Seyd (1997) distinguish between 'social trust' (social capital), which describes reciprocal and horizontal cooperation and relationships between individuals in a given society, and 'political trust' (political capital), which refers to individuals' vertical positions and thoughts concerning the political system. What is meant by the 'political system' here is not the administration in office at any specific time, but a wider understanding of regime. The more a political system is trusted, the more influential and legitimate a status that political system will enjoy. Political trust and social trust are closely related. Whiteley and Seyd point out only one aspect of this relationship. To them, political trust is actually a vertical version of social trust, and social activities (social trust) can generate political trust. The opposite is also probable; political trust is a significant factor in the generation of effective social trust within the boundaries of functional and democratic rules.

What is most lacking in the region, or rather, the matter which needs to be given priority in order to open the way for civil society development, are strategies to promote political trust. An important civil society representative ${ }^{4}$ confirmed that significant changes were made to allow civil society to conduct activities more easily, adding that the one thing that has not changed is the trust issue in state-society relations that continues to have a negative impact. He claimed that as long as the trust issue is not resolved, all other changes become meaningless, and compared the present situation with the 1990s to clarify the current state of events. In 1994, he had led various civil society activities, under very difficult conditions, to protest the foundation of an oil prospecting company whose environmental standards were in violation of the law. However, due to the existing lack of trust in the region, only about 100 people took part in the environmental protests. He argued that were he to repeat the same activities now, he would work in much easier conditions, but due to the

\footnotetext{
${ }^{4}$ Interview with Lezgin Yalçın, who has worked at noteworthy civil society organisations in the Region and is currently the Regional Office Coordinator of the EU-funded Civil Society Development Centre (10 July 2008).
} 
continued lack of trust, he suspected he would not be able to find even 100 people to participate this time.

As the President of the Diyarbakır Bar Association, another noteworthy civil society organisation, said, "The Kurds are going through a very critical process; their bond with this Republic is a weak one, they don't feel as though they fully belong. The state needs to strengthen this sense of belonging among its citizens of Kurdish origin. This emotion is weak among Kurds, hence the tendency to consider violence as a legitimate means" (Yenisafak Daily 2008). As seen, a weak sense of belonging is by no means an absolute and unchangeable characteristic, but rather expresses a sense of hurt by a large group of people toward the attitude and policies of the state.

Also the results of a research conducted among the religious minority group of Syriacs that had to migrate to other European countries due to the difficult conditions of the previous decades reveal the lack of trust prevalent in the region ${ }^{5}$. During the post-2000 period, another important development has taken place in the Anatolian region as a result of the acceleration of the Europeanisation process: Several thousands of Syriacs have begun to return to their former lands indefinitely or for long-term stays. This was particularly noticeable in 2002-2003, when the EU reforms gained most pace and the conflict in the South-eastern Anatolian region began to show a decreasing trend,. In 2004 and 2005 (considering that preparations for return migration would take some time), the rate of return migration reached high levels. However, when compared with the fact that the Syriac Disapora population from this region remains more than 100,000 , then the amount of return migration still seems very low. In fact, according to the opinions of some Syriac authorities ${ }^{6}$ (see also Boyacı 2004), more and more Syriacs want to return to their lands but concerns resulting from (1) the fact that problems in enforcement continue despite the legal reforms and (2) worries regarding the continuity of the reform process, prevent them from returning.

There are, in fact, more blatant examples for explaining the lack of trust in the Anatolian region. Through the adopted reforms, the present administration of Turkey has been to date the most active administration in terms of the Europeanisation of the nation and the Anatolian region. However, Prime Minister R. Tayyip Erdoğan has protested against the publicly-elected Mayor of Diyarbakır, and has refused to shake his hand under any circumstance, on the grounds that the Mayor does not acknowledge the PKK as a terrorist organisation. In turn, the Mayor is distant to the state representatives in the province. This lack of trust between leading, top-level administrators inevitably reflects on other administrators and officials within the same institutions, as well as on their relations with the public.

An environment where conflicts and lack of trust dominate not only prevents the emergence of civil initiatives and wide-scale citizen participation, but also causes those that do emerge to become extremely politicized and partisan in character due to reactive impulses. This situation is different from the political function that civil society is meant to play, and may be described as deviation from it. Independent of founding objectives or activity areas, political reasons and partisan ideas dominate among the NGOs in question (Içduygu and Dane 2005: 23). This is actually not a situation that is peculiar to civil society organisations or their members, nor is it necessarily intentional. People feel pressure that their activities will be interfered with and develop a sense of mistrust, which inevitably causes each and every undertaken activity to be laden with the weight of political problems. The words of a top-level member of the local governing body summarize this point rather ironically (cited in Bumin 2008): "No

\footnotetext{
${ }^{5}$ The research conducted in June 2008 covers a 20-question survey administered to 58 Syriacs residing in Midyat and attached villages and interviews with Syriac authorities and writers. The results of the research will be published in the next months.

${ }^{6}$ Interview with Yakup Gabriel, the President of the Midyat Syriac Association (07 June 2008).
} 
matter what issue we address, even say 'organic farming,' the discussion will without a doubt come around to the Kurdish problem".

There were many Kurdish people among those who immigrated to various European countries, most of all to Germany, from Turkey from the 1960s onwards. This group of people, who initially went as migrant workers but included more asylum seekers especially after 1980, had begun to form their own civil organisations even from the 1960 s onwards, thanks to the suitable legal and political environment in their host countries (Blatte 2006). In Germany alone, where about 600,000 Kurds reside, there are close to 200 Kurdish NGOs and participation rates are quite high (Vatan Daily 2007). The fact that civil organisations and activities noted here as being non-existent in the Anatolian region were in fact taking place in other European countries as early as the $1960 \mathrm{~s}$, serves as an indicator of the inadequacy of the legal and democratic environment within Turkey. More importantly, in the 1960s and 1970s, the people who mostly came together for economic and social solidarity and cohesion and were generally unaware of their ethnic and cultural identities, gained a sense of ethnic and cultural awareness in these groups (Lucassen 2005). With the increase of antidemocratic and militarist methods in the region, especially in the aftermath of the 1980 military coup, an organised Diaspora emerged that fulfilled the political function we stated was lacking in regional NGOs. Emerging as a reaction to the mentioned erroneous domestic policies and actually aiming to prevent them, this political function ended up becoming radically nationalist in tone. Not only did the civil organisations of Kurds in European countries incorporate this political function, they organised activities across Europe and even established offices in major urban centres such as Brussels, and also began to lobby European institutions (Blatte 2006), achieving something that this article has noted was lacking in the Anatolian region.

Consequently, what needs to be done is to establish the necessary democratic-legal grounds and an environment of trust so that existing or to-be-formed civil society organisations can freely carry out the functions stated above. Since great leaps have been taken to establish the legal-democratic grounds via the rapidly enacted reforms as part of the EU membership process, the problem appears to be one of implementation based on the limited environment of trust. Therefore, approaches that will enhance a feeling of trust and communication between the state and the residents of the region must be given priority. Meanwhile, national and regional NGOs have confirmed that problems related to the legal-democratic structure have indeed been overcome. The process of change has been extremely well met by regional and national NGOs, and the most favourable aspects of the process are seen to be the legal framework changes geared toward civil society, and the fact that it has helped the construction of an environment that promotes democratic values (TUSEV and CIVICUS 2006: 18).

In the following section the matter of trust will be elaborated upon. There will also be a discussion about a parameter which is significant in terms of developing political and social trust and that has been observed so far to be neglected by the politicalbureaucratic elite. Correct steps taken on the basis of this parameter will boost the impact of post-2001 changes, hasten normative transformation, and empower civil society.

\section{The road that leads to trust: discourse}

One of the most critical aspects of efforts to boost political trust, actually the starting point of the whole process, is determining which discourse to employ. Explanations in relation to discourse will be based on Schmidt's (2000) distinction between two aspects of discourse. Schmidt differentiates between the discourse used to ascertain a common language and framework among policy elites and to persuade this group of elites of the justification for these changes (coordinative discourse), and the discourse 
necessary to persuade the wider public and ensure vital policy changes achieve success especially at the paradigmatic level (communicative discourse). In terms of the region, where conflict abounds and a sense of belonging is weak, dwelling on both discourses will be imperative.

\section{Coordinative discourse}

While Schmidt describes coordinative discourse as the discourse used among policy makers, it could also be appropriate to include central and regional policy enforcers in executive positions in this definition. This decision was based on the two major benefits expected of coordinative discourse already mentioned above, namely a common language and persuasion of justifications that become crucial especially when changes to delicate issues such as democratization and the expansion of human rights is in question. Under these circumstances, the political elite, civil servants and other public officials that work either centrally or in the region as state representatives will have to be re-trained, and it will be necessary to determine a new coordinative discourse geared toward them. In this paper, coordinative discourse will be employed not only to explicate a specific policy or legal changes, but also to help the parties it addresses to comprehend that a change has occurred in the understanding of the state and citizen that they have held perhaps throughout their professional lives.

Only after the envisioned mentality has been internalised will professional behaviour patterns and habits change more easily. Although noteworthy institutional-legal changes have been made since 2001, it is possible to state that the problems encountered in practice, and the complaints expressed sometimes as if nothing has changed, largely stem from the fact that the coordinative discourse has not yet been given serious importance. Despite the other previous legal changes toward democratization (for example, the new Law of Associations (TUSEV-CIVICUS 2006: 75), enacted in 2004, shows that the legal attitude of the state toward civil society has significantly altered), a study conducted among Regional NGO representatives, found that frequent state interference in NGO work was still a widespread complaint (içcouygu and Dane 2005: 20). This may occur because public authorities continue to view associations with their perspectives and habits of old. Since in the 1990s public officials were always suspicious of the smallest grouping and gathering, and acted on the belief that there may be other underlying reasons for the gathering. Therefore, the legalbureaucratic order bestowed them with extensive powers to deal with such groups, an outcome that was basically inevitable. Although the legal-bureaucratic order has undergone significant changes in recent years, the fact that problems are still ongoing stems from an environment of mistrust and in terms of public authorities, lack of education. The fact that police forces interfered with a women's festival in Diyarbakır, based on the idea that "political slogans may be voiced" is but one example of continued old habits (içcluygu and Dane 2005: 20). The representatives of civil society organisations in the Anatolian region also note that public officials have yet to reach desired levels in terms of adapting to new rules and of changing behavioural patterns.?

Actually, before the regional-local elite and bureaucrats adapt to the shifting structure through coordinative discourse, it will be necessary to make a much more important policy change that will contribute to the same outcome. For decades now, as a longstanding (and unwritten) public administration rule that still continues, Southeastern Anatolia has been seen as a deprived region, one people are often banished to as punishment, and public officials who do not perform well or are deemed undesirable by the centrally-located political-bureaucratic elite still continue to be appointed to posts here. If this situation is to change, it is imperative that skilled and

\footnotetext{
${ }^{7}$ Interviews with Lezgin Yalçın (see footnote 4) and Yılmaz Akıncı, working as a manager in Diyarbakır Industrialists' and Businessmen's Association (11 July 2008).
} 
dynamic individuals be assigned to posts in the region, both in terms of their personal transformation, and in building bridges of trust with the civil community.

\section{Communicative Discourse}

For the legal reforms enacted as part of the EU membership process to succeed, merely persuading the political-bureaucratic elite and training them will not be sufficient; the persuasion, support and dynamism of the public at large is also necessary. What is meant by support here is to ensure (civil) society views change in a positive light, whereas dynamism is meant to express that the changes are not only promoted by but that participation actually ensues. In this circumstance, communicative discourse via its two dimensions functions to realise persuasion, support and participation of the public.

In other words, communicative discourse, via its technical-material dimension, aims to increase levels of knowledge concerning the realized changes and the opportunities provided to them as part of the EU process. Via its normative dimension, it should aim to directly boost political trust, as described above, and raise public support and develop collaborative efforts. A closer look at these two dimensions will help to better explain why communicative discourse must be accorded significance in the region:

- Levels of Knowledge Must Be Raised

Low levels of knowledge obviously hinder public participation in civil organisations. A significant portion of the public, including educated individuals, lacks the legal and technical knowledge and equipment concerning civil organising and activity planning, and thus is indifferent to it all (İçduygu and Dane 2005: 18). These people are also unaware of the reforms enacted as part of the EU process, and the EU programs that are geared toward them. Existing NGOs have stated that they lacked sufficient information on EU programs, and even if this were not the case that they lacked the capacity to actually develop a project and apply to these programs, adding the need for regional support centres that would help NGOs in these matters (TUSEV-CIVICUS 2006).

Although it is not specifically about NGOs, the following example may help reflect the status of the group of educated people in society: According to the findings of a questionnaire (Samur 2007) administered among seniors at Dicle University in Diyarbakir, where close to 90 per cent of the respondents were originally from the Eastern and South-eastern Anatolian regions, only about 6 per cent of the respondents said they were sufficiently informed about training and similar programs of the EU geared specifically toward them. On the other hand, a large proportion of these respondents, most of whom will graduate in the coming year and join the potential workforce, endorsed Turkey's EU membership due to high economic and educational expectations. In other words, while the respondents had expectations, they were unaware of the tools within their reach that could meet these expectations.

Of the 13 EU Documentation Centres in Turkey, none is situated in the Anatolian region. With the exception of a centre established at Gaziantep University, which actually is virtually inactive, nearly all academic centres working on European studies are found in universities in the western part of Turkey. The two EU Information Bureaus founded under the auspices of the Chambers of Commerce in Gaziantep and Diyarbakır, constitute the only places in the region to access information.

Many of the Central and Eastern European countries that recently became EU members began to implement their own Communication Strategies in addition to the programs envisioned for them by the EU (for instance Hungary in 1995, the 
Czech Republic in 1999, and Bulgaria in 2002). These strategies aimed to increase public awareness about the EU, and also to inform civil society and other target groups about the reforms being enacted in the country and available EU programs. As yet, such an extensive and systematic program does not exist in Turkey.

Under these circumstances, for NGOs to object to public officials' unfounded intrusion with their work that remain from earlier times, does not seem possible. In this regard, lack of knowledge simply serves to the continuation of old behavioural patterns and distrustful relations.

- Boosting Support and Dynamism:

A reality that emerged from the 1970s onwards within the context of the EU's own development adventure is that in democratic systems, the role that the public at large will play must be taken into consideration if significant changes are to be realised (Sinnot 1995). This point is a vital one, if problems of trust and legitimacy are to be overcome and the transformation process is to be effective. Therefore, communicative discourse, which enables communication between the ruling class and the general public, is not a concept restricted to merely conveying information. As Checkel (1999: 552) argues, it is actually a process of diffusion of new changes through societal mobilisation including non-state actors and policy networks, and through social learning, where agents, particularly elite decision-makers, adopt prescriptions to constitute 'a set of shared intersubjective understandings' that make behavioural claims.

First of all, communicative discourse must be able to eradicate any uncertainties. To ensure that the positive atmosphere brought on by the reforms continues and an environment that promotes democratic dialogue becomes permanent. Civil society must also be convinced that the reforms are not transient and the achieved rights are safeguarded. Only then will it be possible to garner support. As mentioned before, the return migration of Syriacs has remained limited in the post2000 period due to people's doubt about the sustainability of changing process.

It is especially important that top-level state officials stand behind their policies and promises with the discourse that they employ, in order to assuage any uncertainties and help civil society gain courage. Residents of the Anatolian region have suffered the most from terrorism, violence and oppression, yet as the potential participants of civil society, the fact that they expect determination and sincerity with regard to democracy and human rights, is very understandable. An example of this is an incident that occurred in November 2004. At this time, an event that previously used to occur much more frequently happened; it was announced that a father and his 12-year-old son had been killed by security forces, on the grounds that they were terrorists, armed, and resisting arrest. Leaving aside the allegations of both parties and various groups, Prime Minister R. Tayyip Erdoğan made a statement that differed from the attitudes of other high-level politicians to date, saying, "No matter what, my conscience will not allow me to call a 12-year-old child a terrorist"; the people of the Anatolian region considered this to be a positive and promising development, and thought this new discourse was a sign that from then on, everything would be different. This incident truly did come across as a change in the official discourse of the state; however, steps that would firmly endorse this new communicative discourse, expressed only in this single sentence, were neither taken during the investigation of this incident, nor in subsequent policies, and thus the opportunity to collaborate with civil society within this context did not become permanent.

Communicative discourses must be extensive, in terms of both geography and demography. It was mentioned above that an already weak civil society was almost non-existent in rural areas. Consequently, change makes itself felt in rural areas 
much more slowly. On the other hand, it was also noted that women's education levels were low, and women stayed away from civil society activities. It is imperative that the political elite include rural folk and women in their work to ascertain the context of the discourse that has been envisioned as the first step toward extensive policies geared toward changing structural problems.

Communicative discourse must also be interactive. Extensive public discussions must be encouraged and the views of relevant stakeholders must be sought during the process of policy formulation (Schmidt 2000). Reciprocal communication and transparency must continue during the policy implementation phase, and any complaints must be taken into consideration. As a priority, the views of NGOs, which are in fact the articulated form of societal tendencies and opinions, must also be sought during this process. Through an interactive process such as this, civil society groups will see that they are considered stakeholders, which will in turn contribute to the development of feelings of trust. This may, perhaps, be one of the reasons why the rapid reforms enacted after 2001 have not been able to take root as quickly, at least in the Anatolian region. Officials of DOGUNSIFED, which is an umbrella civil organisation of numerous businessmen's associations in the region, have complained that decision-makers and implementers of the reforms and the EU harmonisation process have not once sought the opinions of relevant groups. ${ }^{8}$ A representative of another civil society organisation confirmed this when he said, "public authorities tend to underestimate the role of civil society organisations and to consider them problem-generating bodies, not problem-solving."

\section{Conclusion}

The role played by civil society in democratic-liberal transformation processes has become more apparent in the last two decades, and boosted its importance. Based on this point, in this study, certain statements were made about the path civil society development may follow in the South-eastern Anatolian region; a region which in the future may constitute the eastern end of the EU and currently is Turkey's most troubled region due to its political, economic and social conditions.

The South-eastern Anatolian region is currently experiencing a transitory phase, where the longstanding environment of conflict and violence is relatively diminished, and democratic methods, at least, are given a wider space in problem resolution. This is a transitory period that Turkey as a nation is also going through, the most significant reason for it being the reform process that gained speed after 2001 as part of EU membership efforts. In addition to these reforms, as a result of EU programs that provide financial-technical support, crucial opportunities for the development of civil society in the South-eastern Anatolian region have become possible.

As this article has tried to demonstrate, in order for these opportunities to bear fruit and the reforms to achieve success, the first and most important thing that needs to be done is to establish social peace and an environment of trust between state and civil society. One important point for the establishment of such an environment is, above all, dependent on the credibility of public authorities and the political elite, and the extent to which they convince the public that some things have indeed changed. Whether they are convincing or not depends, above all, on the extent to which the communication style and discourse employed by political-bureaucratic actors can also adapt to change, in a way that is inclusive of regional concerns.

\footnotetext{
8 Information obtained from electronic correspondence and during meetings held with representatives of DOGUNSIFED (Federation of Eastern and South-eastern Industrialists' and Businessmen's Associations).

${ }^{9}$ Interview with Lezgin Yalçın (see footnote 4).
} 
Another point is to raise people's level of knowledge. Following the path of the Central and Eastern European countries, Turkey should launch a comprehensive Communication Programme to raise people's awareness of and support for the EU. This programme would naturally include legal-institutional reforms. If such a program were to be implemented, it would be necessary to take regional disparities into consideration and employ selective tools to educate the public and raise awareness. If citizens and civil society organisations, as well as political-bureaucratic actors, know their rights and responsibilities in the new period, then it will be easier to establish and develop the environment of communication and trust.

Although general structure and effectiveness of civil society in the region is weak, there are a couple of prominent and dynamic civil society organisations founded in recent years which basically benefit from the Europeanisation process and EU funds (Society Volunteers Foundation, Civil Society Development Centre, GAP Entrepreneur Support and Guidance Centre, etc.). These organisations should function as leading figures and take responsibility for the development of civil society understanding without waiting for the change of the mentality of public authorities. In this regard, it would not be so wrong to consider the simultaneous input-output roles played by NGOs in Central and Eastern European countries in terms of their impact on the transformation process, as an example for the leading organisations in South-eastern Anatolia. This dual role comes to the fore especially in terms of the political function of civil society. By undertaking monitoring and advisory tasks relevant to their activity areas, these NGOs will be able to prevent the difficulties and violations that may occur in the implementation of the crucial reforms enacted as part of the EU membership process. As reforms are implemented and violations diminish, these and other NGOs will find it easier to pursue their work and also make it possible for new NGOs to form. Subsequently, members of an NGO concerned with organic farming will be able to focus on their own work, rather than spend their energy on problems at a macro level. The option of filing a lawsuit with the European Human Rights Court, and the close monitoring of the EU Commission, will also empowers civil society.

Although simplifying the issue along the lines of trust and discourse may present certain risks in terms of fully revealing the truth of the matter, at one point it becomes inevitable when discussing a topic that is so multi-dimensional in character and mostly comprising of parameters that do not lend themselves to measurement. As was said at the beginning, micro-analyses and research studies that complement and modify one another are imperative in terms of understanding the civil society phenomenon and the processes of change, that are gradually becoming more critical both in Turkey and in the EU. Thus, this study, which is considered a significant cross-section of an extensive research study that is presently ongoing, must be supported with further research on issues that have been observed as being neglected in Turkey and especially in the Anatolian region.

***

\section{References}

Bideleux, R. and Jeffries, I. (1998). A History of Eastern Europe. London: Routledge.

Blatte, A. (2006). 'The Kurdish Movement: Ethnic Mobilization and Europeanization', in $\mathrm{H}$. Kleinschmit (ed.), Migration, Regional Integration and Human Security. Burlington: Ashgate.

Boyacl, S. (2004). '2004'e Girerken'. Available at: http://suryaniler.com/konukyazarlar.asp?id=320, last accessed 12 June 2008.

Bulmer, S. and C. Lequesne (2002). New Perspectives on EU-Member State Relationships. Available at: http://www.ceri-sciences-po.org/publica/question/qdr4.pdf, last accessed 20 March 2008.

Bumin, K. (2008). 'Diyarbakır'dan zor sorularla döndüm', Yenişafak Daily. 12 March 2008. 
Checkel, J. T. (1999). 'Social Construction and Integration', Journal of European Public Policy 6 (4), pp. 545-560.

Chirot, D. (1989). 'Causes and Consequences of Backwardness', in D. Chirot (ed.), the Origins of Backwardness in Eastern Europe. Berkeley: University of California Press.

Cohen J. L. and A. Arato (1997). Civil Society and Political Theory. 4th ed., Massachusetts: MIT Press.

COM (Commission of the European Communities) (2001). European Governance-A White Paper. Available at: http://ec.europa.eu/governance/white_paper/index_en.htm, last accessed 16 March 2008.

Dansuk, E., M. Özmen and G. Erdoğan (2006). Poverty and Social Stratification at the Regional Levels in Turkey. Available at:

http://www.eizg.hr/AdminLite/FCKeditor/UserFiles/File/EIZ\%202006\%20Confer ence\%20Proceedings-Dansuk-Ozmen-Erdogan.pdf, last accessed 15 February 2008.

Delanty, G. and C. Rumford (2005). Rethinking Europe: Social Theory and the Implications of Europeanization. London: Routledge.

Deth, J. W. (1997). 'Introduction: Social Involvement and Democratic Politics', in J. W. Deth (ed.), Private Groups and Public Life. London: Routledge.

Edwards, M. (2004). Civil Society. Oxford: Blackwell.

ESI (European Stability Initiative) (2007). Sex and Power in Turkey: Feminism, Islam and the Maturing of Turkish Democracy. Available at: http://www.esiweb.org/pdf/esi document id 90.pdf, last accessed 18 February 2008.

Eurostat. (2007). Europe in Figures 2006/200. Available at: http://epp.eurostat.ec.europa.eu/cache/ITY_OFFPUB/KS-CD-06-001/EN/KS-CD06-001-EN.PDF, last accessed 12 March 2008.

Freedomhouse (2007). Country Report-Turkey. Available at: http://www.freedomhouse.org/uploads/ccr/country-7291-8.pdf, last accessed 15 February 2008.

Hall, J. A. (1995). 'In Search of Civil Society', in J. A. Hall (ed.), Civil Society: Theory, History, Comparison. Cambridge: Polity Press.

Hulme, D. and M. Edwards (1997). 'NGOs, States and Donors: An Overview', in D. Hulme and M. Edwards (eds.), NGOs, States and Donors : Too Close for Comfort?. London: Macmillan and Save the Children Fund.

İçduygu, A. and M. Dane (2005). Report: Türkiye'de Bölgesel Düzeyde Sivil Toplum Degerlendirmesi. İstanbul: TUSEV and CIVICUS.

Lucassen, L. (2005). The Immigrant Threat. Chicago: University of Illinois Press.

Moyser, G. and G. Parry (1997). 'Voluntary Associations and Democratic Participation in Britain', in J. W. Deth (ed.), Private Groups and Public Life. London: Routledge.

Newton, K. (1999). 'Social Capital and Democracy in Modern Europe', in J. W. Deth et al. (eds.), Social Capital and European Democracy. London: Routledge.

Norton, R. A. (1995). 'Introduction', in R. A. Norton (ed.), Civil Society in the Middle East. New York: E. J. Brill.

Ntvmsnbc, 'Metinler', 2 December 2004. Available at: http://www.ntvmsnbc.com/news/298947.asp, last accessed 19 February 2008.

OECD (2007). Regions at a Glance. Paris: OECD Publishing.

Radaelli, C. 2003. 'The Europeanization of Public Policy', in K. Featherstone and C. Radaelli (eds.), The Politics of Europeanization. Oxford: Oxford University Press.

Schmidt, V. A. (2000). 'Democracy and Discourse in an Integrated Europe and Globalising World', European Law Journal 6 (3), pp. 277-300.

Smismans, S. (2005). 'European Civil Society: Institutional Interests and the Complexity of a Multi-level Policy', in S. Rossteutscher (ed.), Democracy and the Role of Associations: Political, Organisational and Social Contexts. London: Routledge.

Sönmez, M. (2007). Doğu-Guneydoğu'nun Artan Yoksulluğu ve Çözüm: Barış. Available at: http://eski.bianet.org/static/dogu2.pdf, last accessed 12 January 2008.

TÜIK (Turkish Statistical Institute) (2001).Report available at: http://www.tuik.gov.tr/Bolgesellstatistik/tabloOlustur.do, last accessed 07 January 2008. 
TUSEV (The Third Sector Foundation of Turkey) and CIVICUS (World Alliance for Citizen Participation) (2006). Türkiye'de Sivil Toplum: Bir Değişim Süreci/Uluslararası Sivil Toplum Endeksi Projesi Türkiye Ülke Raporu. İstanbul: TUSEV

UPSAM (International Politics and Strategy Research Centre) (2006). Report: AB Yolunda Türkiye. Available at: http://www.doratasarim.com/upsam/node/249, last accessed 05 February 2008.

Vatan Daily (2007). 'PKK'nın yıllık bütçesi ne kadar?', 2 November 2007.

Wagner, P. (2006). 'Introduction', in P. Wagner (ed.), the Languages of Civil Society, Oxford: Berghahn Books.

Whiteley, P. F. and P. Seyd (1997). 'Political Capital Formation Among British Party Members', in J. W. Deth (ed.), Private Groups and Public Life, London: Routledge.

Yenisafak Daily (2008). 'Interview with Sezgin Tanrıkulu', 23 February 2008. 